\title{
Resistance and Tolerance of Landrace Wheat in Fields Infested with Pratylenchus neglectus and $P$. thornei
}

Richard W. Smiley, Professor, Jennifer A. Gourlie, Faculty Research Assistant, Guiping Yan, Research Associate, and Karl E. L. Rhinhart, Senior Faculty Research Assistant, Oregon State University, Columbia Basin Agricultural Research Center, Pendleton 97801

\begin{abstract}
Smiley, R. W., Gourlie, J. A., Yan, G., and Rhinhart, K. E. L. 2014. Resistance and tolerance of landrace wheat in fields infested with Pratylenchus neglectus and $P$. thornei. Plant Dis. 98:797-805.

Pratylenchus neglectus and $P$. thornei reduce wheat yields in the Pacific Northwest of the United States. Resistant landrace cultivars have been identified using controlled environments. Field resistance and tolerance characteristics were compared over 3 years and two locations for four spring wheat cultivars: the susceptible 'Alpowa' and 'Louise' and the resistant landraces AUS28451 and Persia 20. Proportions and densities of $P$. neglectus and $P$. thornei differed across seasons and locations. Resistance was evaluated by comparing preplant and postharvest densities of nematodes in soil. Tolerance was evaluated by comparing grain yield and grain quality in plots treated or untreated by

the nematicide aldicarb. Alpowa was susceptible and intolerant, Louise was susceptible and moderately tolerant, AUS28451 was resistant and intolerant, and Persia 20 was moderately susceptible and moderately intolerant. The species dominance shifted from $P$. neglectus to $P$. thornei in one field over a period of 3 years in apparent response to cultivars and crops planted. Estimates of economic loss caused by Pratylenchus spp. ranged from $\$ 8$ to $\$ 20 /$ ha. Economic benefits appear to be achievable by developing a spring wheat genotype with tolerance plus resistance, such as with a cross between AUS28451 and Louise.
\end{abstract}

Root-lesion nematodes (Pratylenchus neglectus (Rensch) Filipjev Schuurmanns \& Stekhoven and P. thornei Sher \& Allen) occur as individual or mixed populations in a majority of the rainfed fields in low-precipitation regions of the Pacific Northwest (PNW) states of Idaho, Montana, Oregon, and Washington $(8,9,25,30)$. These root-lesion nematode species often occur as mixtures in infested fields and both species substantially reduce grain yields for spring and winter wheat (Triticum aestivum L.; 20,23,27,28). It was estimated that these Pratylenchus spp. reduce the farm-gate revenue for wheat by at least $\$ 51$ million annually from the 1.7 million ha planted annually in the states of Idaho, Oregon, and Washington (20).

Practices recommended for managing the impacts of Pratylenchus spp. are currently limited $(21,24)$. These practices include rotations to crop species that are not typically produced in the region or planting tolerant cultivars that may not produce the highest grain yields in fields with low nematode densities. Currently, there are no resistant varieties or chemical or biological nematicides available to manage these root parasites. Development of cultivars with genetic resistance will be important to reduce Pratylenchus spp. densities in soil, thereby reducing the economic risk associated with planting intolerant cultivars or crops into infested fields.

Wheat cultivars that greatly suppress reproduction of nematodes are classed as resistant and those that allow high rates of reproduction are susceptible (3). Wheat cultivars resistant to P. neglectus are not necessarily resistant to $P$. thornei, and vice versa $(14-18,33)$. Wheat cultivars with an ability to withstand or recover from nematode invasion and to yield well in comparison with noninvaded plants are classed as tolerant and sensitive plants are considered as intolerant (3). Tolerance is usually estimated in the field by comparing the yield of a wheat cultivar in a naturally infested soil that is either left untreated or is treated with the nematicide aldicarb $(5,11,20,31,35-37)$. Genotypes with comparable yields in both

Corresponding author: R. Smiley, E-mail: richard.smiley@oregonstate.edu

Accepted for publication 16 December 2013.

http://dx.doi.org/10.1094/PDIS-10-13-1069-RE

(C) 2014 The American Phytopathological Society treatments are tolerant and genotypes with yields that are considerably higher in treated than in untreated soil are intolerant.

Wheat cultivars with both resistance and tolerance are required for optimal performance in existing plantings as well as for reducing the risk to subsequent plantings of intolerant cultivars or crops (26). Most commercial wheat cultivars tested in the PNW are susceptible and intolerant to both $P$. neglectus and $P$. thornei $(14,16$ $18,20,33)$. Several imported landrace wheat cultivars were resistant to both $P$. neglectus and $P$. thornei under controlled conditions (1418,33 ) but have not been examined for tolerance or resistance in the field.

The objectives of this research were to compare resistance and tolerance of two resistant and two susceptible wheat cultivars over a period of 3 years at two locations having mixtures of $P$. neglectus and $P$. thornei. Comparison of yields in plots treated or not treated with nematicide was used as an estimate of tolerance. Postharvest densities of Pratylenchus spp. in soil of control plots (not treated with nematicide) were used as an estimate of resistance.

\section{Materials and Methods}

Experimental sites. Trials were performed near Mission and Pendleton, OR in a Mediterranean, semiarid climate having cool, moist winters and warm, dry summers. Each field was selected based on previous knowledge that it was infested by $P$. neglectus, P. thornei, or a mixture of these species.

Trials during 2011, 2012, and 2013 were located on different sites within a single field managed by the Confederated Tribes of the Umatilla Indian Reservation (CTUIR), located $10 \mathrm{~km}$ southeast of Pendleton in Umatilla County, at $450 \mathrm{~m}$ of elevation and coordinates $45^{\circ} 37.853^{\prime} \mathrm{N}, 118^{\circ} 41.130^{\prime} \mathrm{W}$; hereafter, these trials are referred to as Mission. The experimental sites within the Mission location were located within $200 \mathrm{~m}$ of one another. This location receives $330 \mathrm{~mm}$ of mean annual precipitation, nearly all of which occurs from late autumn (November) through spring (May). The soil is a Hermiston silt loam, a deep (>200 cm), coarse-silty, mixed, mesic Cumulic Haploxeroll (42). The field was maintained without tillage (no-till) and was planted to winter wheat 'Madsen' and 'Rod' (1:1 blend) during 2008, left as unplanted chemical fallow during 2009, and planted to no-till canola 'DeKalb RR 536' during 2010. The trial during 2011 followed the canola crop of 2010 and was planted on 5 April and harvested on 18 August. The 
2012 trial followed a crop of spring wheat 'Louise' and was planted on 9 May and harvested on 22 August. The 2013 trial also followed a crop of Louise and was planted on 18 March and harvested on 8 August.

Trials identical to those at Mission were conducted during the same years near Pendleton. Trials were performed at the Oregon State University Columbia Basin Agricultural Research Center 14 $\mathrm{km}$ northeast of Pendleton, in Umatilla County, at $457 \mathrm{~m}$ of elevation and coordinates of $45^{\circ} 43.158^{\prime} \mathrm{N}, 119^{\circ} 37.656^{\prime} \mathrm{W}$. Annual precipitation averages $442 \mathrm{~mm}$ and the soil is a variable-depth (90 to $150 \mathrm{~cm}$ ) Walla Walla silt loam; a coarse-silty, mixed, superactive, mesic Typic Haploxeroll. The trial during 2011 was on a field managed as a 3-year no-till rotation of winter wheat, spring wheat, and chemical fallow. This trial was planted on 5 April following the harvest of winter wheat 'ORCF 102' during July 2010. The trial during 2012 was in a no-till field planted annually to wheat; spring wheat Louise preceded this experiment during 2012. The trial was planted on 9 May and harvested on 22 August. During 2013, another field in the 3-year no-till rotation of winter wheat, spring wheat, and chemical fallow was used. This trial was planted on 18 March following the harvest of winter wheat ORCF 102 during July 2012.

Experimental design and treatments. Each trial consisted of six replicates of each cultivar entry planted as a split-plot design. Replicates were blocks placed successively across the experimental area. Cultivars were randomized within each replicate (main plot) and each plot was split (subplots) as an adjacent nematicide-treated or nontreated plot. Each treatment consisted of four drill rows in 1.8-by-9-m plots. Four spring wheat cultivars were evaluated. Cultivars included two that are susceptible and two that are resistant to $P$. neglectus and P. thornei under controlled environments.

'Alpowa' (PI566596) was the most-planted soft white spring wheat cultivar in the PNW from 1997 to 2006 (40) and was used as a control. It was derived from the pedigree Fielder/Potam 70//Walladay/3/Walladay/Potam70 (1). Alpowa was reported as being susceptible to $P$. neglectus and $P$. thornei $(14-16,33)$ and as intolerant to P. neglectus and moderately tolerant to P. thornei (20).

Louise (PI634865) succeeded Alpowa as the leading soft white spring wheat cultivar in the PNW (41) and served as a second control. Louise was derived as a cross between cultivars 'Wakanz' and 'Wawawai' (10) and was reported as susceptible to P. neglectus and $P$. thornei $(14-16,33)$ and moderately intolerant to both $P$. neglectus and P. thornei (20).

AUS28451 (PI621458; CIMMYT CWI57134) is a hard white spring landrace wheat line collected near Sharghi, East Azerbaijan. AUS28451 had been selected in Australia for resistance to $P$. thornei (19). In the PNW, AUS28451 was highly resistant to both $P$. neglectus and $P$. thornei (14-16) under controlled conditions but had not been evaluated for field resistance or tolerance to these root-lesion nematode species.

Persia 20 (AUS5202; CI 11283) is a hard white facultative landrace wheat line of Iranian origin selected for resistance to $P$. neglectus in Australia (39). In the PNW, Persia 20 was moderately resistant or resistant to both $P$. neglectus and $P$. thornei (14-16). However, conflicting reports in the United States and Australia indicated that Persia 20 was susceptible to P. thornei $(33,38)$. This line had not been evaluated for resistance or tolerance to rootlesion nematodes under field conditions in the PNW.

Seed was planted with or without application of the nematicide aldicarb (4.2 kg/ha, as Temik 15G; Bayer CropScience). Untreated controls and aldicarb treatments were in adjacent drill rows (subplots) to provide side-by-side comparisons of cultivar performance in treated and untreated plots.

A locally fabricated no-till drill was used to plant each trial. The drill was equipped with a cone-seeder, two Gandy distributors, and four series of row openers spaced at $36 \mathrm{~cm}$. Fluted opening coulters were mounted on a front tool bar and were followed by a sweep-type deep-bander for dispensing fertilizer. A second toolbar was used to mount double-disk openers to dispense seed in line with the opening coulter and deep bander. One Gandy distributor was used to dispense fertilizer $5 \mathrm{~cm}$ below and $4 \mathrm{~cm}$ to each side of the seed row. Aldicarb was metered from a second Gandy distributor on the drill and was placed into the seed row in alternate drill rows (subplots). Seed was dispensed through a cone seeder at a rate of 205 seeds $/ \mathrm{m}^{2}$ and was placed into moist soil at $3 \mathrm{~cm}$ of depth.

Seed during 2011 was treated with difenoconazole plus mefanoxam $(0.18+0.04 \mathrm{~g} / \mathrm{kg}$, as Dividend Extreme; Syngenta Crop Protection). Seed treatment during 2012 and 2013 included difenoconazole, mefanoxam, ipconazole, and thiamethoxam $(0.18+0.04$ $+0.02+0.13 \mathrm{~g} / \mathrm{kg}$, as a proprietary custom blend from Pendleton Grain Growers). Preplant weed control using glyphosate and postharvest broadleaf weeds in each trial were managed using standard practices for the weed species of importance at each location.

Fertilizer was applied at the time of planting and was banded by the seed drill. For five of the six trials, the fertilizer was applied as $\mathrm{N}$ at $123 \mathrm{~kg} / \mathrm{ha}$, formulated as a $1: 1$ blend of $16-20-0$ and $46-0-0$ (Pendleton Grain Growers). During 2011, wet soil caused the fertilizer shanks to plug at Mission. Therefore, the same fertilizer blend was broadcast onto the soil surface 1 week after planting, using a rate of $\mathrm{N}$ at $145 \mathrm{~kg} / \mathrm{ha}$.

During 2012, stripe rust (Puccinia striiformis) in each experiment was prevented by two applications of propiconazole plus trifloxystrobin $(12+12 \mathrm{~g} / \mathrm{ha}$, as Stratego; Bayer CropScience).

Wheat yield and quality assessment. Grain yields and test weights were calculated after harvesting entire plots using a Hege plot combine (Wintersteiger Inc.). The effect of Pratylenchus spp. on wheat quality was estimated by comparing test weights in control and nematicide treatments. Test weight estimates the plumpness of wheat kernels and its potential for efficient milling. Minimal test weights for U.S. No. 1-5 are 78.9, 76.4, 73.8, 71.2, and $67.3 \mathrm{~kg} / \mathrm{hl}$, respectively (4).

Nematode assessment and identification. Preplant density of plant-parasitic nematodes in each experimental area $\left(800 \mathrm{~m}^{2}\right)$ was determined by collecting two composite soil samples from each experimental area at or before the time of planting. Each composite sample consisted of 25 soil cores of $2.5 \mathrm{~cm}$ in diameter by $30 \mathrm{~cm}$ in depth.

Postharvest nematode densities during 2011 were determined by collecting samples consisting of a composite of 20 soil cores $(2.5$ $\mathrm{cm}$ in diameter by $30 \mathrm{~cm}$ in depth) in each $17-\mathrm{m}^{2}$ plot. Due to dry soil conditions, sampling during 2012 and 2013 consisted of cores being collected using a tractor-mounted Giddings GSTRS Hydraulic Soil Sampler (Giddings Machine Company) with a 5-cm-diameter, $150-\mathrm{cm}$-long slotted soil tube. Two soil cores separated by 2 $\mathrm{m}$ were collected to a $30-\mathrm{cm}$ depth in each plot. Soil from the two cores was composited into a single sample for each plot. The two sampling methods have provided highly correlated results (23). The mechanized sampling device is favored when soils are dry following harvest.

Initial and postharvest soil samples were submitted to Western Laboratories (Parma, ID) for extraction and enumeration of nematodes. Dry samples were moistened and incubated at ambient laboratory air temperature for at least 1 week before nematodes were extracted. A modified Oosterbrink elutriator and centrifugal flotation extraction method was used (6). Vermiform nematodes and heteroderid cysts were extracted and collected on separate sieves. Cysts were broken to release eggs plus juveniles and the suspension was combined with the suspension of vermiform nematodes. The composite suspension was then concentrated through multiple sequences of centrifugation and density flotation using a magnesium sulfate solution (6), as described by Smiley and Machado (23). The density of plant-parasitic nematodes was reported and nematodes were identified to the genus level.

Pratylenchus spp. present at each location were identified during previous research $(25,27,28,43-45)$. Samples of nematode suspensions from Western Labs were also returned to our laboratory for identification of Pratylenchus spp. in randomly selected samples. Identification of species was made by examining features such as vulval position and tail shape $(2,7)$ and by examining DNA of 
nematodes extracted directly from soil using species-specific endpoint polymerase chain reaction (PCR) or real-time PCR (43-45). The PCR band patterns or the melting curve profiles were compared with that of DNA from pure nematode control cultures.

Resistance ratings were scaled on the basis of postharvest Pratylenchus spp. densities averaged across years and locations, and compared with the mean density following the susceptible commercial cultivar Alpowa. Ratings were resistant (postharvest Pratylenchus spp. densities $<25 \%$ of the susceptible control entry Alpowa), moderately resistant (26 to 50\%), moderately susceptible (51 to $75 \%$ ), and susceptible $(\geq 76 \%)$. Tolerance ratings were scaled on the basis of mean improvement of grain yield between nematicide-treated and untreated plots when averaged across years and locations. Ratings were tolerant $(<5 \%$ mean increase in grain yield), moderately tolerant (6 to $10 \%$ ), moderately intolerant (11 to $15 \%)$, and intolerant $(\geq 16 \%)$.

Statistical analyses. Data grouped across locations during each year were analyzed as a split-split plot design to examine treatment effects of trial location, cultivar, and nematicide, using trial as the main plot factor, cultivar as the subplot factor, nematicide as the sub-subplot factor, and replicates as blocks. Analyses were performed using CoStat Statistical Software version (Co-Stat v. 6.400; CoHort Software). Within individual experiments, the means for grain yield, grain test weight, and nematode density were analyzed as a split-plot design, with cultivar as the main plot, nematicide treatment as the subplot, and replicates as blocks. Data were also analyzed individually for control and nematicide treatments at each location, using the randomized complete block design, with cultivars as main effects and replicates as blocks. When treatment means were significant at $\alpha<0.05$, means were separated using the Tukey's honestly significant difference (HSD) test when numbers of replicates were equal for all treatments, and the least significant difference (LSD) test when replicates or treatments were unequal. Analyses were performed on nematode density data normalized by using the $\ln (x+1)$ transformation. Logarithmic means were back transformed into real numbers for presentation in the tables. The percent change in Pratylenchus spp. density over the life cycle of the wheat plant was calculated for cultivars in untreated control plots by using the formula $\%$ change $=100(P f-P i) / P i$, where $P f$ was the nontransformed mean density per kilogram of soil for replicates of a specific cultivar after harvest, and $P i$ was the mean density for the experimental area prior to planting.

Economic analysis. Yield data averaged over years were evaluated to estimate the economic impact of yield suppression by Pratylenchus spp. Yield improvement from application of nemati- cide was multiplied by the average farm-gate value of wheat sales for the corresponding year. Wheat price was based upon the monthly average reported for the Portland, OR export market, available at http://www.ers.usda.gov/data-products/wheat-data. aspx. The potential economic impact of yield improvement from growing a resistant variety was calculated by comparing average grain yield for two locally adapted cultivars, Alpowa and Louise, in soil treated or untreated with nematicide. Yields in treated plots were assumed to be comparable with what may have been produced by the same cultivars if nematode densities had been reduced to an extent which had no influence on potential grain yield.

\section{Results}

Preplant density of Pratylenchus spp. Initial densities of Pratylenchus spp. at Mission and Pendleton were lower during 2011 than during 2012 or 2013. At Mission, there were 1,316 Pratylenchus spp./kg of soil during 2011. There was a much greater proportion of Pratylenchus neglectus than $P$. thornei but specific proportions were not determined. During 2012, preplant density was 12,144 Pratylenchus spp./kg of soil (2:1 ratio of $P$. thornei to P. neglectus). During 2013, the preplant nematode density was 26,400 Pratylenchus spp./kg of soil (9:1 ratio of $P$. thornei to $P$. neglectus). Therefore, the proportion of Pratylenchus spp. changed within the single field at Mission during the course of this investigation. This trend could not be assessed at Pendleton, where different fields were used each year. Similar to results at Mission, population densities of Pratylenchus spp. at Pendleton were lower in 2011 than in 2012 and 2013. In 2011, there were 1,213 P. thor$n e i / \mathrm{kg}$ of soil. During 2012, the preplant samples contained 6,732 Pratylenchus spp./kg of soil. During 2013, there were 10,516 Pratylenchus spp./kg of soil (3.3:1 ratio of $P$. thornei to $P$. neglectus).

Postharvest density of Pratylenchus spp. The postharvest density of Pratylenchus spp. was significantly $(\alpha<0.01)$ influenced each year by the main effects of cultivar and nematicide (Table 1). The effect of trial location was also significant during 2012 and 2013. All three main effects were significant when data were grouped over 3 years. Few interactions among main effects were significant at $\alpha<0.05$ (data not presented) and none were considered as being biologically significant. The cultivar-location interaction was significant each of the 3 years and the interactions of nematicide-location and nematicide-cultivar interactions were significant during 2012, the year in which a late planting led to abnormally late growth and low yields for the region.

Averaged across cultivars and trial locations, the application of nematicide reduced nematode densities by 68,65 , and $50 \%$ during

Table 1. Significance of main treatment effects for data presented in Tables 2, 3, and $4^{\mathrm{z}}$

\begin{tabular}{|c|c|c|c|c|c|c|}
\hline \multirow[b]{2}{*}{ Year, treatment effect } & \multicolumn{2}{|c|}{$\begin{array}{c}\text { Postharvest Pratylenchus spp./ } \\
\text { kg of soil }\end{array}$} & \multicolumn{2}{|c|}{ Grain yield (kg/ha) } & \multicolumn{2}{|c|}{ Grain test weight $(\mathrm{kg} / \mathrm{hl})$} \\
\hline & df & $P>F$ & df & $P>F$ & df & $P>F$ \\
\hline \multicolumn{7}{|l|}{$\overline{\text { Year } 1(2011)}$} \\
\hline Trial & 1 & 0.1051 & 1 & $<0.0001$ & 1 & $<0.0001$ \\
\hline Cultivar & 3 & 0.0001 & 3 & $<0.0001$ & 3 & $<0.0001$ \\
\hline Nematicide & 1 & $<0.0001$ & 1 & $<0.0001$ & 1 & $<0.0001$ \\
\hline \multicolumn{7}{|l|}{ Year 2 (2012) } \\
\hline Trial & 1 & $<0.0001$ & 1 & $<0.0001$ & 1 & 0.7691 \\
\hline Cultivar & 3 & 0.0058 & 2 & $<0.0001$ & 2 & $<0.0001$ \\
\hline Nematicide & 1 & $<0.0001$ & 1 & $<0.0001$ & 1 & $<0.0001$ \\
\hline \multicolumn{7}{|l|}{ Year 3 (2013) } \\
\hline Trial & 1 & $<0.0001$ & 1 & $<0.0001$ & 1 & 0.3284 \\
\hline Cultivar & 3 & $<0.0001$ & 3 & $<0.0001$ & 3 & 0.0003 \\
\hline Nematicide & 1 & $<0.0001$ & 1 & $<0.0001$ & 1 & 0.0031 \\
\hline \multicolumn{7}{|l|}{ Grouped over 3 years } \\
\hline Trial & 1 & $<0.0001$ & 1 & 0.1320 & 1 & $<0.0001$ \\
\hline Cultivar & 3 & $<0.0001$ & 3 & $<0.0001$ & 3 & $<0.0001$ \\
\hline Nematicide & 1 & 0.0031 & 1 & $<0.0001$ & 1 & $<0.0001$ \\
\hline
\end{tabular}

${ }^{\mathrm{z}}$ Experimental design was a split-split plot with trial locations as main plots, cultivars as subplots, nematicide treatments as sub-subplots, and replicates $(n=$ 6) as blocks. Degrees of freedom for year 2 differed between grain production parameters and nematode density data because one cultivar could not be harvested during 2012. 
2011, 2012, and 2013, respectively (Table 2). The reductions in densities were greater at Pendleton than at Mission during 2011 (83 versus 59\%) and 2013 (61 versus $48 \%$ ), and were greater at Mission than at Pendleton during 2012 (68 versus 57\%). Nematode population densities were significantly reduced by application of nematicide for Alpowa, Louise, and Persia 20 each year at both locations (Table 2). The nematode population densities following AUS28451 were generally reduced by nematicide at Pendleton but not at Mission. Relative to Alpowa, the postharvest densities of Pratylenchus spp. in untreated control plots were significantly higher following Louise during two of six site years of observation, with each of those instances occurring at Pendleton during 2 years of "normal" wheat productivity (Tables 2 and 3). In untreated control plots, the postharvest densities of Pratylenchus spp. were significantly lower following Persia 20 than Alpowa in three of six site years of observation, with each of those instances occurring at Mission. The postharvest densities following AUS28451 were significantly lower than following Alpowa during each of the five site years in which that comparison could be made.

The lowest postharvest densities of Pratylenchus spp. were always detected in plots of the resistant landrace wheat line AUS28451. The final densities of Pratylenchus spp. in control plots following Persia 20 were always higher than that following AUS28451. The highest densities of Pratylenchus spp. occurred in control plots planted to one of the locally adapted cultivars (Alpowa or Louise). In the control treatment, the final nematode densities were as much as 12 times higher following Alpowa compared with following AUS28451, which occurred during 2012 at Mission (Table 2). When all six experiments were grouped, final Pratylenchus spp. densities were reduced for all cultivars when nematicide was applied (Table 4). However, density in control plots was always least following AUS28451, which was the only entry with significantly fewer Pratylenchus spp. than Alpowa and Louise.

Alpowa, Louise, and Persia 20 were each rated as susceptible to these Pratylenchus spp. (Table 4). Reductions in nematode densities in response to nematicide application were 37 to $86 \%$ for the commercial cultivars during the course of the experiment (Table 2). AUS28451 was rated resistant (Table 4). Postharvest densities of Pratylenchus spp. for AUS28451 in untreated controls were always lower than for other cultivars and reductions due to nematicide application were significant in only two of the five observations, both of which occurred at Pendleton, where P. thornei was the dominant species (Table 2). Compared with Alpowa, AUS28451 significantly reduced Pratylenchus spp. densities in control plots in each of the five observations available. Persia 20 was rated as moderately susceptible (Table 4). Compared with Alpowa, Persia 20 significantly reduced the nematode densities in all three trials at Mission but not in the three trials at Pendleton (Table 2), possibly due to the greater prevalence of $P$. neglectus in the species mixture at Mission than at Pendleton.

Each year, the percent change in Pratylenchus spp. densities over the growing season was neutral to positive for Alpowa and Louise and negative for AUS28451 and Persia 20 (Fig. 1). The percent change was always significantly different between AUS28451 and the commercial control cultivars, and between AUS28451 and Persia 20. These findings support the designations of AUS28451 as resistant, Persia 20 as moderately susceptible, and Alpowa and Louise as susceptible to species of Pratylenchus present at these sites.

Other nematode genera and species detected. Several plantparasitic nematode genera and species other than Pratylenchus spp. were detected during these studies. Low numbers of stunt nematodes (Tylenchorhynchus spp.) were detected at each site during 2011 (292 and 324 Tylenchorhynchus spp./kg of soil at Mission and Pendleton, respectively) but not during preplant samplings in 2012 or 2013 . Very small numbers of stunt nematodes $(<40$ nematodes $/ \mathrm{kg}$ of soil) were detected in 3 of the 48 plots at the Pendleton site during postharvest sampling in 2013. Previous experience at nearby sites $(25,29)$ has shown that the stunt nematodes were likely to be Tylenchorhynchus clarus. During 2012, the preplant samples at Pendleton included Heterodera avenae at 44 nematodes $/ \mathrm{kg}$ of soil but this nematode was not detected in any other sampling. The stubby root nematode (Trichodorus spp.) was detected at a low

Table 2. Postharvest density of Pratylenchus spp. (nematodes $/ \mathrm{kg}$ of soil) in naturally infested fields following growth of four spring wheat cultivars treated or untreated by nematicide during 3 years at Mission and Pendleton, $\mathrm{OR}^{\mathrm{x}}$

\begin{tabular}{|c|c|c|c|c|c|c|c|c|c|c|c|c|}
\hline \multirow[b]{2}{*}{ Year, cultivar } & \multicolumn{4}{|c|}{ Mission } & \multicolumn{4}{|c|}{ Pendleton } & \multicolumn{4}{|c|}{ Two-location means } \\
\hline & Control & Treated & $\operatorname{Rdc}(\%)^{\mathrm{y}}$ & $\operatorname{Rel}(\%)^{\mathrm{z}}$ & Control & Treated & $\operatorname{Rdc}(\%)$ & $\operatorname{Rel}(\%)$ & Control & Treated & $\operatorname{Rdc}(\%)$ & $\operatorname{Rel}(\%)$ \\
\hline \multicolumn{13}{|l|}{2011} \\
\hline Alpowa & $3,858 \mathrm{a}$ & $1,034 \mathrm{ab}$ & $73 *$ & - & $2,101 \mathrm{~b}$ & 486 & $77 *$ & - & $2,980 \mathrm{~b}$ & 760 & $74 *$ & _- \\
\hline Louise & $4,530 \mathrm{a}$ & $2,380 \mathrm{a}$ & $47 *$ & +17 & $4,852 \mathrm{a}$ & 728 & $85^{*}$ & $+131^{*}$ & $4,691 \mathrm{a}$ & 1,554 & $67 *$ & $+57^{*}$ \\
\hline AUS28451 & $732 \mathrm{~b}$ & $556 \mathrm{~b}$ & 24 & $-81 *$ & $\mathrm{nt}$ & $\mathrm{nt}$ & - & - & $732 \mathrm{c}$ & 556 & 24 & $-75^{*}$ \\
\hline Persia 20 & $2,375 \mathrm{ab}$ & $711 \mathrm{~b}$ & $70 *$ & $-38^{*}$ & $1,952 \mathrm{~b}$ & 264 & $86^{*}$ & -7 & $2,164 \mathrm{~b}$ & 488 & $77 *$ & -27 \\
\hline Mean & 2,874 & 1,170 & $59 *$ & $\ldots$ & 2,968 & 493 & $83^{*}$ & $\ldots$ & 2,642 & 840 & $68^{*}$ & $\ldots$ \\
\hline$P>F$ & 0.0068 & 0.0170 & $\ldots$ & $\ldots$ & 0.0007 & 0.6738 & $\ldots$ & $\ldots$ & $<0.0001$ & 0.1082 & $\ldots$ & $\ldots$ \\
\hline \multicolumn{13}{|l|}{2012} \\
\hline Alpowa & $35,514 \mathrm{a}$ & $14,062 \mathrm{a}$ & $60 *$ & - & $6,789 \mathrm{a}$ & $4,700 \mathrm{a}$ & $44 *$ & - & $21,151 \mathrm{a}$ & $9,381 \mathrm{a}$ & $56 *$ & - \\
\hline Louise & $32,737 \mathrm{a}$ & $6,432 a b$ & $80 *$ & -8 & $6,568 \mathrm{a}$ & $1,433 a b$ & $78^{*}$ & -3 & $19,652 \mathrm{a}$ & $3,933 a b$ & $80 *$ & -7 \\
\hline AUS28451 & $3,007 \mathrm{~b}$ & $3,073 \mathrm{~b}$ & -2 & $-92 *$ & $1,193 \mathrm{~b}$ & $530 \mathrm{~b}$ & $56^{*}$ & $-82^{*}$ & $2,100 \mathrm{~b}$ & $1,802 \mathrm{~b}$ & 14 & $-90^{*}$ \\
\hline Persia 20 & $11,843 \mathrm{ab}$ & $3,376 \mathrm{~b}$ & $71 *$ & $-67 *$ & $5,474 \mathrm{a}$ & $1,986 \mathrm{ab}$ & $64 *$ & -19 & $8,559 a$ & $2,681 \mathrm{~b}$ & $69 *$ & $-60 *$ \\
\hline Mean & 20,775 & 6,736 & $68 *$ & $\ldots$ & 5,006 & 2,162 & $57^{*}$ & $\ldots$ & 12,866 & 4,449 & $65^{*}$ & $\ldots$ \\
\hline$P>F$ & 0.0015 & 0.0507 & $\ldots$ & $\ldots$ & 0.0438 & 0.0204 & $\ldots$ & $\ldots$ & 0.0001 & 0.0008 & $\ldots$ & $\ldots$ \\
\hline \multicolumn{13}{|l|}{2013} \\
\hline Alpowa & $42,357 \mathrm{ab}$ & $20,360 \mathrm{~b}$ & $52 *$ & - & $6,352 \mathrm{ab}$ & 3,666 a & $42 *$ & - & $24,354 \mathrm{a}$ & $12,013 \mathrm{a}$ & $51^{*}$ & - \\
\hline Louise & $55,504 \mathrm{a}$ & $32,416 \mathrm{a}$ & $42 *$ & +31 & $9,743 \mathrm{a}$ & $4,104 \mathrm{a}$ & $58 *$ & $+53^{*}$ & $32,624 \mathrm{a}$ & 18,260 a & $44 *$ & $+34 *$ \\
\hline AUS28451 & $5,342 \mathrm{c}$ & $5,891 \mathrm{~d}$ & -10 & $-87 *$ & $1,696 \mathrm{c}$ & $223 \mathrm{~b}$ & $87 *$ & $-73^{*}$ & $3,519 \mathrm{~b}$ & $3,057 \mathrm{~b}$ & 13 & $-86^{*}$ \\
\hline Persia 20 & $27,083 \mathrm{~b}$ & $9,386 \mathrm{c}$ & $37 *$ & $-36^{*}$ & $4,907 \mathrm{~b}$ & $866 \mathrm{ab}$ & $82 *$ & -23 & $15,995 \mathrm{a}$ & $5,126 \mathrm{~b}$ & $68 *$ & $-34 *$ \\
\hline Mean & 32,572 & 17,013 & $48^{*}$ & $\ldots$ & 5,675 & 2,215 & $61^{*}$ & $\ldots$ & 19,123 & 9,614 & $50 *$ & $\ldots$ \\
\hline$P>F$ & $<0.0001$ & $<0.0001$ & $\ldots$ & $\ldots$ & 0.0308 & 0.0159 & $\ldots$ & $\ldots$ & $<0.0001$ & $<0.0001$ & $\ldots$ & $\ldots$ \\
\hline
\end{tabular}

${ }^{x}$ Pratylenchus spp. included mixtures of Pratylenchus neglectus and P. thornei at Mission, and mostly P. thornei at Pendleton; numbers are backtransformed means from the $\ln (x+1)$ transformation used to analyze data for statistical analysis; $\mathrm{nt}=$ not tested. Nematicide treatment included application of aldicarb banded into the seed row at the time of planting. Numbers followed by the same letter within a column are not significantly different at $\alpha<0.05$ as determined by Tukey's honestly significant difference test, based upon analysis of $\ln (x+1)$ transformed data.

${ }^{y}$ Percent reduction of Pratylenchus spp. density in nematicide treatment compared with the untreated control. Differences that are significantly different $(\alpha<$ $0.05)$ from the controls are designated by an asterisk $(*)$.

${ }^{\mathrm{z}}$ Nematode density in untreated control treatments, relative to that of the Alpowa control. Differences that are significantly different $(\alpha<0.05)$ from Alpowa are designated by an asterisk $(*)$. 
density (176 Trichodorus spp./kg of soil) during preplant but not postharvest sampling at Mission during 2013; the species was not determined and was not detected in other samplings.

Plant growth and grain yield. Establishment of seedling stands was excellent for each of the six trials (data not presented). A laterthan-usual planting date during one very wet spring (2012) caused AUS28451 to remain mostly vegetative and to produce too few heads to be harvested.

Main treatment effects for grain yield were significant $(\alpha<$ 0.0001 ) each year for cultivar, nematicide, and trial location (Table 1). The cultivar-location interaction was significant for grain yield each year and, during 2012, the nematicide-location and the nematicide-cultivar interactions were also significant. When yield data were grouped over years, the main effects for cultivar and nematicide were highly significant.

When data were grouped across the four cultivars and two nematicide treatments, the mean grain yield was greater at Mission than at Pendleton each year; 4,328 versus $3,411 \mathrm{~kg} / \mathrm{ha}\left(\mathrm{HSD}_{0.05}=\right.$ $381), 1,248$ versus $700 \mathrm{~kg} / \mathrm{ha}\left(\mathrm{HSD}_{0.05}=156\right)$, and 2,449 versus $2,115 \mathrm{~kg} / \mathrm{ha}\left(\mathrm{HSD}_{0.05}=152\right)$ during 2011, 2012, and 2013, respectively (Table 3 ). Application of nematicide increased mean grain yield by 16, 77, and 19\% during 2011, 2012 and 2013,

Table 3. Grain yield (kg/ha) of four spring wheat cultivars in fields naturally infested with Pratylenchus spp. and treated or untreated by nematicide during 3 years at Mission and Pendleton, $\mathrm{OR}^{\mathrm{x}}$

\begin{tabular}{|c|c|c|c|c|c|c|c|c|c|}
\hline \multirow[b]{2}{*}{ Year, cultivar } & \multicolumn{3}{|c|}{ Mission } & \multicolumn{3}{|c|}{ Pendleton } & \multicolumn{3}{|c|}{ Two-location means } \\
\hline & Control & Treated & Incr. $(\%)^{y}$ & Control & Treated & Incr. $(\%)$ & Control & Treated & Incr. $(\%)$ \\
\hline \multicolumn{10}{|l|}{ Year 1 (2011) } \\
\hline Alpowa & 4,217 & $5,337 \mathrm{a}$ & $27 *$ & $3,344 \mathrm{~b}$ & $4,192 \mathrm{a}$ & $25^{*}$ & $3,780 \mathrm{a}$ & $4,765 \mathrm{a}$ & $26^{*}$ \\
\hline Louise & 4,263 & $4,831 \mathrm{a}$ & $13 *$ & $4,031 \mathrm{a}$ & $4,138 \mathrm{a}$ & 3 & $4,147 \mathrm{a}$ & $4,485 \mathrm{a}$ & 8 \\
\hline AUS28451 & 4,115 & $4,728 \mathrm{a}$ & $15^{*}$ & nt & $\mathrm{nt}$ & - & $4,115 \mathrm{a}$ & $4,729 \mathrm{a}$ & $15^{*}$ \\
\hline Persia 20 & 3,216 & $3,910 \mathrm{~b}$ & $22 *$ & $2,325 \mathrm{c}$ & $2,437 \mathrm{~b}$ & 5 & $2,770 \mathrm{~b}$ & $3,174 \mathrm{~b}$ & $15^{*}$ \\
\hline Mean & 3,953 & 4,702 & $19 *$ & 3,233 & 3,589 & $11^{*}$ & 3,644 & 4,225 & $16^{*}$ \\
\hline $\mathrm{LSD}_{005}$ & $\mathrm{~ns}$ & 563 & $\ldots$ & 440 & 527 & $\ldots$ & 389 & 341 & $\ldots$ \\
\hline$P>F$ & 0.1018 & 0.0007 & $\ldots$ & $<0.0001$ & $<0.0001$ & $\ldots$ & $<0.0001$ & $<0.0001$ & $\ldots$ \\
\hline \multicolumn{10}{|l|}{ Year $2(2012)^{\mathrm{z}}$} \\
\hline Alpowa & $1,200 \mathrm{a}$ & $2,208 \mathrm{a}$ & $84 *$ & $647 \mathrm{a}$ & $1,162 \mathrm{a}$ & $80 *$ & $923 \mathrm{a}$ & $1,635 \mathrm{a}$ & $77 *$ \\
\hline Louise & $1,078 \mathrm{a}$ & $1,690 \mathrm{~b}$ & $57 *$ & $740 \mathrm{a}$ & $1,022 \mathrm{a}$ & $38^{*}$ & $909 \mathrm{a}$ & $1,356 \mathrm{~b}$ & $49^{*}$ \\
\hline Persia 20 & $323 \mathrm{~b}$ & $987 \mathrm{c}$ & $206^{*}$ & $200 \mathrm{~b}$ & $428 \mathrm{~b}$ & $114^{*}$ & $261 \mathrm{~b}$ & $709 \mathrm{c}$ & $172 *$ \\
\hline Mean & 867 & 1,628 & $88^{*}$ & 529 & 871 & $65^{*}$ & 698 & 1,233 & $77^{*}$ \\
\hline $\mathrm{HSD}_{0.05}$ & 375 & 309 & $\ldots$ & 406 & 333 & $\ldots$ & 204 & 162 & $\ldots$ \\
\hline$P>F$ & $<0.0001$ & $<0.0001$ & $\ldots$ & 0.0018 & 0.0001 & $\ldots$ & $<0.0001$ & $<0.0001$ & $\ldots$ \\
\hline \multicolumn{10}{|l|}{ Year 3 (2013) } \\
\hline Alpowa & 2,498 & $3,054 \mathrm{a}$ & $22 *$ & $2,456 \mathrm{a}$ & $2,777 \mathrm{a}$ & $13 *$ & $2,477 \mathrm{a}$ & $2,916 \mathrm{a}$ & $18^{*}$ \\
\hline Louise & 2,150 & $2,211 \mathrm{~b}$ & 3 & $2,166 \mathrm{a}$ & $2,539 \mathrm{~b}$ & $17 *$ & $2,158 \mathrm{ab}$ & $2,375 a b$ & $10^{*}$ \\
\hline AUS28451 & 2,455 & $3,368 \mathrm{a}$ & $37 *$ & $1,537 \mathrm{~b}$ & $1,992 \mathrm{c}$ & $30 *$ & $1,996 \mathrm{ab}$ & $2,680 \mathrm{a}$ & $34 *$ \\
\hline Persia 20 & 1,815 & $2,038 \mathrm{~b}$ & $12 *$ & $1,598 \mathrm{~b}$ & $1,846 \mathrm{c}$ & $16^{*}$ & $1,707 \mathrm{~b}$ & $1,942 \mathrm{~b}$ & $14 *$ \\
\hline Mean & 2,229 & 2,668 & $20 *$ & 1,940 & 2,289 & $18 *$ & 2,084 & 2,478 & $19^{*}$ \\
\hline $\mathrm{HSD}_{0.05}$ & $\mathrm{~ns}$ & 458 & $\ldots$ & 229 & 174 & $\ldots$ & 402 & 409 & $\ldots$ \\
\hline$P>F$ & 0.1769 & $<0.0001$ & $\ldots$ & $<0.0001$ & $<0.0001$ & $\ldots$ & 0.0039 & 0.0002 & $\ldots$ \\
\hline
\end{tabular}

${ }^{\mathrm{x}}$ Pratylenchus spp. included mixtures of Pratylenchus neglectus and P. thornei at Mission, and mostly P. thornei at Pendleton. Nematicide treatment included application of aldicarb banded into the seed row at the time of planting. Numbers followed by the same letter within a column are not significantly different at $\alpha<0.05$ as determined by Tukey's honestly significant difference (HSD) test; ns = not significant; LSD = least significant difference.

${ }^{y}$ Percent increase in yield due to applications of nematicide. Differences that are significantly different $(\alpha<0.05)$ from the controls are designated by an asterisk $(*)$.

z AUS28451 was planted but not harvested during 2012 because it remained mostly vegetative, apparently due to a failure to vernalize in response to a laterthan-normal planting date.

Table 4. Grain yield (kg/ha) and postharvest density of Pratylenchus spp. (nematodes $/ \mathrm{kg}$ of soil) for four spring wheat cultivars grouped over years at naturally infested field sites treated or untreated by nematicides

\begin{tabular}{|c|c|c|c|c|c|c|c|c|c|}
\hline \multirow[b]{2}{*}{ Cultivar } & \multicolumn{5}{|c|}{ Postharvest Pratylenchus density ${ }^{\mathrm{t}}$} & \multicolumn{4}{|c|}{ Grain yield $^{u}$} \\
\hline & Control & Treated & Reduc. $(\%)^{\mathrm{v}}$ & Rel. $(\%)^{\mathrm{w}}$ & Rating $x$ & Control & Treated & Incr. $(\%)^{\mathrm{y}}$ & Rating \\
\hline Alpowa & $9,974{a b^{z}}^{2}$ & $4,274 \mathrm{a}$ & $57 *$ & 100 & $\mathrm{~S}$ & $3,128 \mathrm{a}$ & $3,840 \mathrm{a}$ & $23 *$ & IT \\
\hline Louise & $13,344 \mathrm{a}$ & $3,928 \mathrm{a}$ & $71^{*}$ & 134 & $\mathrm{~S}$ & $3,152 \mathrm{a}$ & $3,430 \mathrm{a}$ & 9 & MT \\
\hline AUS28451 & $1,982 \mathrm{c}$ & $1,071 \mathrm{~b}$ & $40 *$ & $20 *$ & $\mathrm{R}$ & $2,702 \mathrm{ab}$ & $3,363 \mathrm{a}$ & $24 *$ & IT \\
\hline Persia 20 & $6,403 \mathrm{~b}$ & $1,648 \mathrm{~b}$ & $74 *$ & 64 & MS & $2,239 \mathrm{~b}$ & $2,558 \mathrm{~b}$ & $14 *$ & MI \\
\hline Mean & 7,926 & 2,730 & $65^{*}$ & - & $\ldots$ & 2,805 & 3,298 & $18^{*}$ & $\ldots$ \\
\hline$P>F$ & $<0.0001$ & 0.0004 & $\ldots$ & $\ldots$ & $\ldots$ & 0.0076 & 0.0020 & $\ldots$ & $\ldots$ \\
\hline
\end{tabular}

${ }^{\mathrm{s}}$ Nematicide treatment included application of aldicarb banded into the seed row at the time of planting.

${ }^{t}$ Postharvest Pratylenchus spp. density include data for all site years because AUS28451 exerted similar influences on these nematodes even though it failed to produce heads during 2012. Pratylenchus spp. included mixtures of Pratylenchus neglectus and P. thornei.

" Grain yield data include two trial locations and 2 years (four site years); data for 2012 were eliminated due to abnormally low yields and the failure of one entry (AUS28451) to produce heads due to failure to fully vernalize.

${ }^{\vee}$ Percent reduction in Pratylenchus spp. density due to applications of nematicide. Differences that are significantly different $(\alpha=0.05)$ from untreated control are designated by an asterisk (*).

${ }^{w}$ Nematode density in untreated control treatments, relative to that of the Alpowa control. Differences that are significantly different $(\alpha<0.05)$ from the Alpowa control, based upon analysis of $\ln (x+1)$ transformed data, are designated by an asterisk (*).

${ }^{\mathrm{x}}$ Resistance and tolerance rating scales: $\mathrm{R}=$ resistant (postharvest Pratylenchus spp. density $<25 \%$ of the susceptible control entry Alpowa), MR $=$ moderately resistant $(26-50 \%), \mathrm{MS}=$ moderately susceptible $(51-75 \%), \mathrm{S}=$ susceptible $(\geq 76 \%), \mathrm{T}=$ tolerant $(<5 \%$ mean increase in grain yield), MT $=$ moderately tolerant $(6-10 \%), \mathrm{MI}=$ moderately intolerant $(11-15 \%)$, and $\mathrm{IT}=$ intolerant $(\geq 16 \%)$.

${ }^{y}$ Percent increase in yield due to application of nematicide. Differences that are significantly different $(\alpha<0.05)$ from the untreated control are designated by an asterisk (*).

${ }^{\mathrm{z}}$ Numbers followed by the same letter within a column are not significantly different at $\alpha<0.05$ as determined by Least Significant Difference (LSD) test. 
respectively (Table 3 ). Yields were unusually low at both locations during 2012 and, therefore, were excluded from additional analysis. When grain yield data over both locations were grouped for 2011 and 2013 (Table 4), the main effects were significant $(\alpha<$ 0.01 ) for location, cultivar, and nematicide, and the interaction between location and cultivar was also significant. Application of nematicide increased mean grain yield by $18 \%$ (Table 4 ) and yields in the nontreated controls and in the nematicide-treated plots were statistically similar for Alpowa, Louise, and AUS28451 (Table 4). Yield of Persia 20 was significantly lower than for Alpowa and Louise in each of the control and nematicide treatments.

Alpowa and AUS28451 were categorized as intolerant, Persia 20 as moderately intolerant, Louise as moderately tolerant (Table 4).

Grain quality. Grain test weight differed significantly $(\alpha<$ 0.01 ) each year in response to main effects of cultivar and nematicide (Table 1). When data for 2011 and 2013 were grouped, as explained above, mean test weights across locations were $3 \%$ greater in the nematicide-treated than in the untreated plots: 77.7 versus $75.5 \mathrm{~kg} / \mathrm{hl}$, respectively $\left(\mathrm{LSD}_{0.05}=1.4\right.$; data not shown $)$. Test weights were higher $\left(\operatorname{LSD}_{0.05}=2.1\right)$ for Alpowa $(79.5 \mathrm{~kg} / \mathrm{hl})$, Louise $(78.0 \mathrm{~kg} / \mathrm{hl})$, and Persia $20(77.0 \mathrm{~kg} / \mathrm{hl})$ than for AUS28451 $(70.4 \mathrm{~kg} / \mathrm{hl})$. When test weights of the two locally adapted cultivars were averaged together over 2 years (2011 and 2013) and two trial locations, the test weight was significantly greater $\left(\mathrm{HSD}_{0.05}=1.9\right)$ in nematicide-treated than untreated plots: 79.8 versus $77.7 \mathrm{~kg} / \mathrm{hl}$, respectively. These test weights fall within the limits of market grades U.S. No. 1 and No. 2, respectively. For both control and nematicide treatments, these cultivars each met the standard for U.S. No. 1 at both locations during 2011. However, during 2013 at Pendleton, grain was graded as U.S. No. 2 in each treatment and, at Mission, graded as U.S. No. 2 in the nematicide-treated plots and as U.S. No. 4 in the control plots.

Profitability. When yields for Alpowa and Louise were averaged across 2 years (2011 and 2013) and two trial locations (Table 5 ), the yield improvement from nematicide application was greater for Alpowa (23\%) than for Louise (9\%). Grouped together, the mean yield for these locally adapted cultivars was $16 \%(495 \mathrm{~kg} / \mathrm{ha})$ greater in nematicide-treated plots $(3,645 \mathrm{~kg} / \mathrm{ha})$ than in control plots $(3,140 \mathrm{~kg} / \mathrm{ha})$. Based upon a mean September wheat price of US $\$ 2.72 / \mathrm{hl}$ (\$2.31/hl during 2011 and $\$ 3.13 / \mathrm{hl}$ during 2013), Pratylenchus spp. were estimated to have reduced the average profitability of wheat production in these fields by $\$ 13.90 /$ ha: $\$ 19.69 /$ ha for Alpowa and \$7.88/ha for Louise. For a typical farm in the region, consisting of about 480 ha of wheat planted each

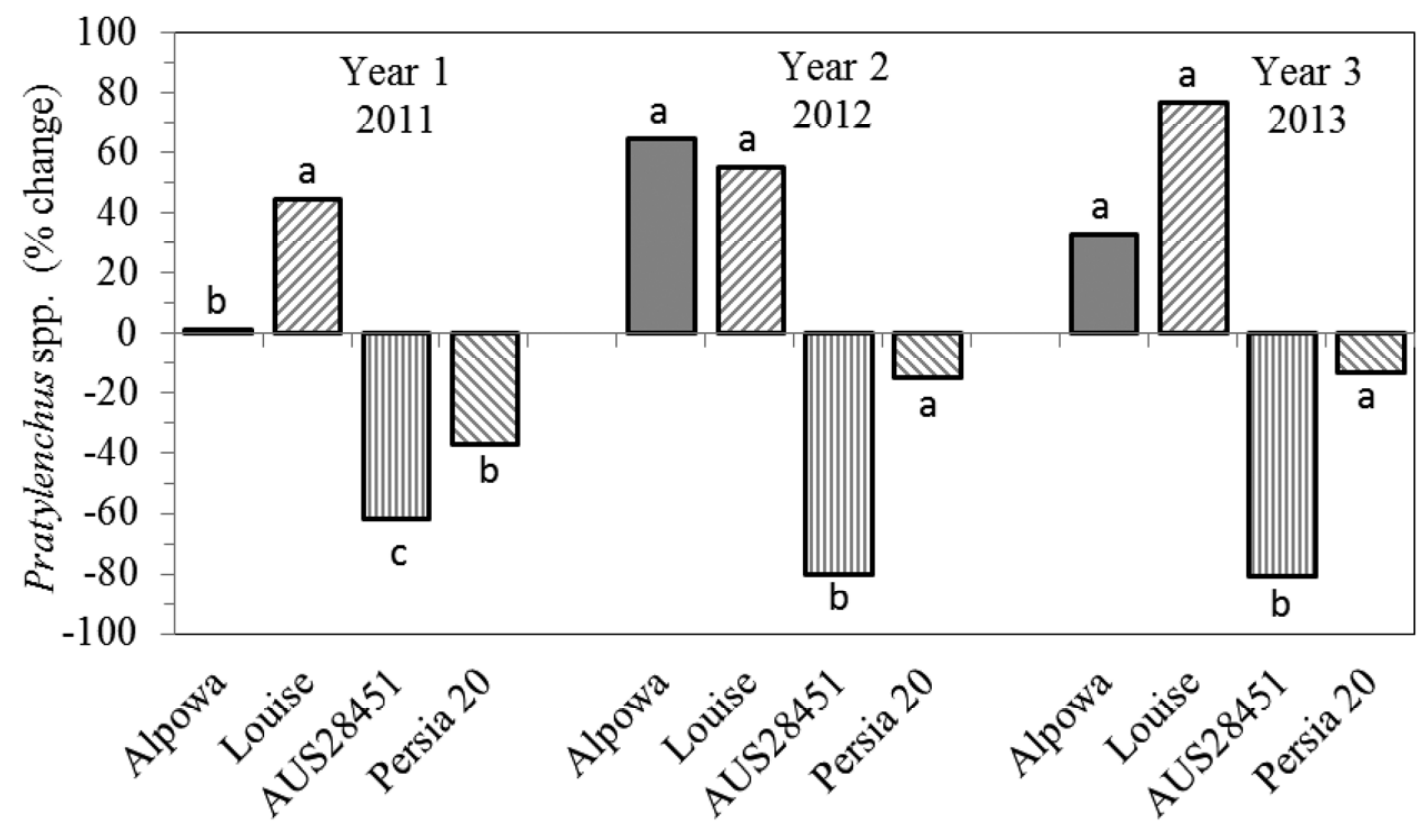

Fig. 1. Percent change in Pratylenchus spp. density during three seasons of growth by four spring wheat cultivars in naturally-infested fields; data for each year are grouped over two locations (Mission and Pendleton, OR) and calculated using the formula \% change $=100(P f-P i) / P i$, where $P f$ and $P i$ were the nontransformed final and initial Pratylenchus spp. densities per kilogram of soil, respectively. Bars labeled with the same letter do not differ at the $\alpha<0.05$ level of significance.

Table 5. Economic value of production for two locally adapted soft white spring wheat cultivars (Alpowa and Louise) produced in Pratylenchus spp.infested fields at two locations (Mission and Pendleton, OR) during 2 years (2011 and 2013) in which production was typical for the region; comparisons are for cultivars produced in plots treated or untreated with nematicide ${ }^{\mathrm{w}}$

\begin{tabular}{|c|c|c|c|c|c|c|}
\hline \multirow[b]{2}{*}{ Grain production and value } & \multicolumn{3}{|c|}{ Alpowa } & \multicolumn{3}{|c|}{ Louise } \\
\hline & Nematicide & Control & Increase & Nematicide & Control & Increase \\
\hline Yield (kg/ha; and \%) & 3,840 & 3,129 & $711(22.7 \%)$ & 3,430 & 3,153 & $277(8.8 \%)$ \\
\hline Test weight $(\mathrm{kg} / \mathrm{hl})$ & 81.1 & 78.0 & $3.1(4.0 \%)$ & 78.6 & 77.4 & $1.2(1.6 \%)$ \\
\hline U.S. Wheat Market Grade ${ }^{\mathrm{x}}$ & No. 1 & No. 2 & $\ldots$ & No. 2 & No.2 & $\ldots$ \\
\hline Volume produced (hl/ha) & 47.3 & 40.1 & $18.0 \%$ & 43.6 & 40.7 & $7.1 \%$ \\
\hline Value $(\$ / h a)^{y}$ & 128.86 & 109.17 & 19.69 & 118.74 & 110.86 & 7.88 \\
\hline Value (\$/average-size farm $)^{\mathrm{z}}$ & 61,851 & 52,402 & 9,449 & 56,997 & 53,213 & 3,784 \\
\hline
\end{tabular}

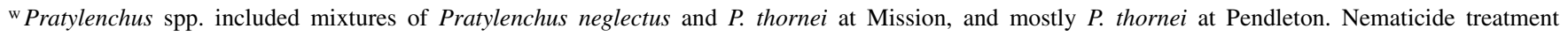
included application of aldicarb into the seed row at the time of planting.

${ }^{x}$ Minimal test weights for the five U.S. Market Grades of soft white wheat are 78.9, 76.4, 73.8, 71.2, and 67.3 kilograms/hl for U.S. No. 1 to 5, respectively (4).

${ }^{y}$ Market prices for soft white wheat at Portland, OR during September averaged $\$ 2.31 / \mathrm{hl}$ and $\$ 3.13 / \mathrm{hl}$ during 2011 and 2013 , respectively (http://www.ers.usda.gov/data-products/wheat-data.aspx).

${ }^{\mathrm{z}}$ Average farm size in the region of this research is approximately 960 ha, about half of which is planted to wheat each year. A farm with 480 ha of soft white spring wheat was assumed for this calculation. 
year, the farm-scale economic impact from nematodes would have equated to a loss ranging from $\$ 3,784$ for Louise to $\$ 9,449$ for Alpowa. The average loss for these two cultivars would have equated to a loss of $\$ 6,671$ to the farm enterprise.

\section{Discussion}

This research provides further evidence that Pratylenchus spp. reduce both wheat yield and grain quality in the PNW. Our estimates from this work indicated that the value of spring wheat production was reduced by $\$ 8$ to $\$ 20 /$ ha in infested fields, depending upon the cultivar planted and the level of infestation. For an average-size farm in the region, this level of crop damage would equate to a reduction in farm profitability of between $\$ 4,000$ and $\$ 10,000$ annually. These are conservative estimates because they did not include a likely reduction in wheat price associated with reduced wheat quality in control plots that were not treated with nematicide, and because application of aldicarb in a Pratylenchus spp.infested field failed to improve yield of an intolerant wheat cultivar to a level equaling that of the same cultivar in a nearby field that had an undetectably low density of $P$. thornei, in comparison with a tolerant cultivar that produced comparable yields under those conditions (34). Because our research was conducted in fields infested with both $P$. neglectus and $P$. thornei, it was not possible to determine whether the commercial cultivars differed in tolerance to one or both individual species. Smiley (20) reported that Louise was more tolerant of $P$. neglectus than of $P$. thornei and Alpowa was more tolerant of $P$. thornei than of $P$. neglectus. Those differences would have been obscured in many of the tests performed in this study at sites with mixtures of these species. During the course of these studies, Louise was more tolerant than Alpowa to the mixtures of Pratylenchus spp. encountered.

We also present the first evidence that a spring wheat genotype with resistance to both $P$. neglectus and $P$. thornei can substantially reduce the postharvest density of mixtures of Pratylenchus spp. in infested fields. This was demonstrated in fields that had varying initial proportions of $P$. neglectus and $P$. thornei during the course of experiments conducted in different fields, different sites within fields, different locations, and over three growing seasons. Owen et al. (13) recently reported a nearly $70 \%$ lower biomass of a $P$. thor$n e i$-intolerant wheat cultivar that was planted after $P$. thornei-susceptible crops compared with more resistant crops in a field infested by $P$. thornei. Although the dual-species resistance trait exhibited by AUS28451 will undoubtedly become important to PNW agriculture, the yield penalty associated with genotypic intolerance to Pratylenchus spp. will limit the acceptance by growers of cultivars that express resistance but not tolerance. In the current investigation, AUS28451 was much less tolerant than Louise. It will be important to introgress resistance from a cultivar such as AUS28451 with the greater tolerance expressed by a cultivar such as Louise. A resistant plus tolerant cultivar would enable growers to attain acceptable yields while also reducing the density of nematodes that pose an increased risk to subsequent plantings of intolerant cultivars or crops. Fortunately, gross yields of AUS28451 were competitive with those of the commercial cultivars, indicating the possibility that high-yielding lines should be able to be identified that also are resistant to P. neglectus and P. thornei.

Although AUS28451 carries traits of Pratylenchus spp. resistance of value to the PNW field crops industries, this cultivar was recently determined to also possess several undesirable agronomic traits that would need to be selected against while incorporating Pratylenchus resistance into lines that could be advanced into commercial cultivars. In particular, Thompson (32) determined that AUS28451 carried traits for leaf and head pubescence and for tenacious glumes. These traits cannot be allowed to be advanced into a commercial cultivar. This same study (32) also identified the presence of the Vrn-Dla vernalization gene in AUS28451, providing evidence that our premise for the failure of this cultivar to produce normal numbers of heads during 2012 resulted from our late planting date and, therefore, an insufficient period of vernalization for the 2012 planting. It was clear that AUS28451 produced heads in a normal manner during other years, and that plantings of this cultivar 2 weeks earlier during 2012 in plots adjacent to both of our trial locations produced a normal number of heads (A. Thompson, unpublished data). Vernalization requirements will be advantageous when the Pratylenchus spp. resistance trait is incorporated into susceptible winter wheat cultivars in the PNW but will be less advantageous for crossing into spring wheat. Fortunately, Thompson (32) also identified other land-race wheat lines having dualspecies resistance to Pratylenchus spp., plus acceptable agronomic traits that include resistance to races of Puccinia striiformis of current importance in the PNW.

AUS28451 was more resistant than Persia 20 to the mixture of Pratylenchus spp. encountered in this study. Although early assays of Persia 20 indicated that this cultivar conferred dual-species resistance (15-17), more recent assays under controlled conditions revealed that Persia 20 enabled reproduction more similar to that of Louise for Pratylenchus neglectus and similar to that of Alpowa for P. thornei $(32,33,38)$. In this study, reproduction of Pratylenchus spp. on Persia 20 was intermediate between that of AUS28451 and the commercial cultivars Alpowa and Louise. These results indicate that future emphasis in the PNW should be shifted from Persia 20 to a landrace having improved agronomic characteristics and resistances comparable with AUS28451 (32).

We detected a shift in proportions of $P$. neglectus and $P$. thornei over a period of 3 years in a field near Mission. Although the experiments were placed on different sites within that field, the experiments each year were all located within $200 \mathrm{~m}$ of one another in a single corner of that field. Shifts over time have also been reported for other Oregon locations. For instance, assays of Pratylenchus spp. in a 12-year cropping systems experiment at another low-precipitation site $(280 \mathrm{~mm})$ in north-central Oregon revealed that winter wheat selected for a dominance of $P$. neglectus and spring wheat selected for a dominance of $P$. thornei (24). Comparable findings of Pratylenchus spp. selections occurred in 83year-old monoculture blocks of cultivated winter wheat and spring wheat and in 16-year-old nontilled blocks of these crops at the Columbia Basin Agricultural Research Center at Pendleton (R. W. Smiley, unpublished). Furthermore, a corresponding difference in species prevalence was reported by wheat producers on two neighboring farms in eastern Idaho which produce only winter wheat or only spring wheat.

In this study, at Mission, P. neglectus was the dominant species during 2011. In this year, the experiment followed multiple crops of winter wheat Madsen and Rod followed by canola. Spring wheat Louise was planted in the field by the grower during 2011 and again in 2012. Therefore, subsequent experiments followed 1 year of Louise during 2012 and 2 years of Louise during 2013. Sheedy et al. $(17,18)$ reported that, in concurrent controlled-environment assays, some popular PNW winter wheat cultivars strongly favored reproduction of $P$. neglectus compared with $P$. thornei. For example, respective relative reproductive values $(\mathrm{Pf} / \mathrm{Pi}=$ final/initial density) were 29 and 7 for ORCF 102, 24 and 7 for Rod, and 31 and 10 for 'Brundage 96'. In contrast, other popular cultivars were less discriminating as hosts for $P$. neglectus and P. thornei. For example, respective Pf/Pi values were 10 and 10 for 'Stephens' and 13 and 18 for Madsen for P. neglectus and P. thornei, respectively. We also recently determined from greenhouse assays that Louise is a much better host of $P$. thornei than of $P$. neglectus, and that multiple cultivars of canola are much better hosts for P. neglectus than for $P$. thornei (R. W. Smiley, unpublished). It is likely that the shift in species dominance at Mission was due more to influences of different wheat genotypes than to differences in plant growth habit (e.g., a 10-month winter wheat crop versus a 4-month spring wheat crop), or with associated differences in temperature and moisture cycles. Because different wheat cultivars vary in tolerance to these two Pratylenchus spp. (20), our recent observations of crop management effects on species dominance indicate an urgent need to incorporate identification of Pratylenchus spp. by commercial nematology laboratories that currently only report this group of nematodes at the genus level. Recent development of DNA-based 
tests can be used to alleviate the difficulties associated with distinguishing $P$. neglectus and $P$. thornei using only morphometric characteristics (43-45).

Aldicarb was used as a research tool in these experiments. This pesticide is not registered for commercial application by wheat producers in the United States. High expense, ecological concerns, and lack of registration preclude it from consideration as a potential solution to crop losses being caused by Pratylenchus spp. Nevertheless, aldicarb is a long-favored research tool for examining effects of plant-parasitic nematodes on wheat $(5,11,20,27,28$, $31,37)$. Aldicarb is typically applied as a band below or with the seed at planting to suppress damage and reproduction of nematodes. This nematicide has a half-life of up to 5 weeks, reduces the Pratylenchus population early in the plant growth period, and results in improved grain yields for genotypes that are intolerant to the nematode $(20,27,28,31)$. Aldicarb is favored for this research use because it does not influence diseases caused by soilborne, root-infecting fungi $(11,12)$ and does not stimulate wheat yield in the absence of plant-parasitic nematodes or insect pests (27); however, it occasionally has been shown to suppress wheat yields due to phytotoxicity or to a more severe expression of root diseases caused by soilborne fungi $(22,27)$.

We clearly demonstrated that Pratylenchus spp. are causing economic losses to the PNW wheat industry, and that resistant cultivars can reduce the level of risk that would be encountered by subsequent plantings of intolerant crops. Specifically, we have shown that imported landrace wheat cultivars such as AUS28451 will play an important role in the development of commercial wheat cultivars that are both resistant and tolerant to Pratylenchus spp.

\section{Acknowledgments}

We thank the Idaho Wheat Commission, Oregon Wheat Commission, Washington Grains Commission, Oregon Agricultural Experiment Station, and the United States Department of Agriculture-Agricultural Research Service Root Disease and Biological Control Unit at Pullman, WA for funding; Western Laboratories (Parma, ID) for providing discounted nematode testing fees; the CTUIR (Mission, OR) for providing land and crop management assistance; and P. Thorgersen, N. Webster, A. Weinke, S. Isbell, and A. Hitzman for technical assistance.

\section{Literature Cited}

1. Carlson, J. R., Betschart, A. A., Heimsch, R. C., and Burke, M. J. 1998. Release of Alpowa (PI566596), a soft white spring wheat. Washington Agricultural Research Center, Pullman, WA. http://washingtoncrop.com/ documents/Wheat/Spring/Soft\%20White/Alpowa.pdf

2. Castillo, P., and Vovlas, N. 2007. Pratylenchus, Nematoda, Pratylenchidae: diagnosis, biology, pathogenicity and management. Nematol. Monogr. Perspect. 6:1-530.

3. Cook, R., and Evans, K. 1987. Resistance and tolerance. Pages 179-231 in: Principles and Practice of Nematode Control in Crops. R. H. Brown and B. R. Kerry, eds. Academic Press, Sydney, Australia.

4. Grain Grading Procedures. 2013. Pages 13-1-13-38 in Grain Inspection Handbook, Book II, Chapter 13. United States Department of Agriculture, Federal Grain Inspection Service, Washington, DC. http://www.gipsa.usda. gov/Publications/fgis/handbooks/grain-insp/grbook2/wheat.pdf

5. Hague, N. G. M., and Gowen, S. G. 1987. Chemical control of nematodes. Pages 131-178 in: Principles and Practice of Nematode Control in Crops. R. H. Brown and B. R. Kerry, eds. Academic Press, Sydney, Australia.

6. Hallmann, J., and Viaene, N. 2013. Nematode extraction: PM 7/119 (1). EPPO Bull. 43:471-495. Online publication. http://onlinelibrary.wiley.com/ doi/10.1111/epp.12077/pdf

7. Handoo, Z. A., and Golden, A. M. 1989. A key and diagnostic compendium to the species of the genus Pratylenchus Filipjev, 1936 (lesion nematodes). J. Nematol. 21:202-218.

8. Johnson, W. A. 2007. Discovery and distribution of root lesion nematode, Pratylenchus neglectus, in Montana. M.Sc. thesis, Montana State University, Bozeman. http://scholarworks.montana.edu/xmlui/bitstream/handle/ 1/1576/JohnsonW1207.pdf?sequence $=1$

9. Kandel, S. L., Smiley, R. W., Garland-Campbell, K., Elling, A. A., Abatzoglou, J., Huggins, D., Rupp, R., and Paulitz, T. C. 2013. A survey of root lesion nematodes (Pratylenchus spp.) and their relationship with climatic factors in dryland wheat production areas of eastern Washington. Plant Dis. 97:1448-1456.

10. Kidwell, K. K., Chen, X. M., Morris, C. F., Bosque Pérez, N. A., Carter, B. P., Shelton, G. B., Demacon, V. L., and Burns, J. W. 2006. Registration of 'Louise' wheat. Crop Sci. 46:1384-1385.

11. Kimpinski, J., and Johnson, H. W. 1995. Effects of aldicarb and fungicides on Pratylenchus penetrans populations, root rot and net blotch severity on barley. Phytoprotection 76:9-16.

12. Kimpinski, J., Johnson, H. W., and Martin, R. A. 1987. Influence of aldicarb on root lesion nematodes, leaf disease and root rot in wheat and barley. Plant Pathol. 36:333-338.

13. Owen, K. J., Clewett, T. G., and Thompson, J. P. 2012. What is the impact of winter grain crops on Pratylenchus thornei grown in rotation with tolerant and intolerant wheat? Page 67 in: Proc. 7th Australas. Soilborne Dis Symp. Fremantle, WA, Australia. W. J. MacLeod, ed. http://www.appsnet. org/Publications/Proceedings/7th\%20ASDS\%20Proceedings.pdf

14. Sheedy, J. G., Raupp, W. J., Thompson, A. L., and Smiley, R. W. 2008 Resistance to root lesion nematodes of Chinese Spring $\times$ Aegilops speltoides addition lines; Pratylenchus neglectus and P. thornei. Plant Dis. Manage. Rep. 2:N038.

15. Sheedy, J. G., Smiley, R. W., Easley, S. A., and Thompson, A. L. 2007. Resistance reaction of Pacific Northwest spring wheat and barley cultivars to root-lesion nematode; Pratylenchus neglectus. Plant Dis. Manage. Rep. 1:CF022.

16. Sheedy, J. G., Smiley, R. W., Easley, S. A., and Thompson, A. L. 2008 Root-lesion nematode resistance reaction of Pacific Northwest spring wheat and barley cultivars; Pratylenchus thornei. Plant Dis. Manage. Rep. 2:N007.

17. Sheedy, J. G., Smiley, R. W., Easley, S. A., and Thompson, A. L. 2008 Root-lesion nematode resistance ratings of Pacific Northwest winter wheat and barley cultivars; Pratylenchus thornei. Plant Dis. Manage. Rep. 2:N015.

18. Sheedy, J. G., Smiley, R. W., Easley, S. A., and Thompson, A. L. 2008. Resistance of Pacific Northwest winter wheat and barley cultivars to rootlesion nematode; Pratylenchus neglectus. Plant Dis. Manage. Rep. 2:N016.

19. Sheedy, J. G., and Thompson, J. P. 2009. Resistance to the root-lesion nematode Pratylenchus thornei of Iranian landrace wheat. Australas. Plant Pathol. 38:478-489.

20. Smiley, R. W. 2009. Root-lesion nematodes reduce yield of intolerant wheat and barley. Agron. J. 101:1322-1335.

21. Smiley, R. W. 2010. Root-lesion nematodes: biology and management in Pacific Northwest wheat cropping systems. PNW Ext. Bull. 617 Oreg. State Univ. Corvallis

22. Smiley, R. W., Ingham, R. E., Uddin, W., and Cook, G. H. 1994. Crop sequences for managing cereal cyst nematode and fungal populations of winter wheat. Plant Dis. 78:1142-1149.

23. Smiley, R. W., and Machado, S. 2009. Pratylenchus neglectus reduces yield of winter wheat in dryland cropping systems. Plant Dis. 93:263-271.

24. Smiley, R. W., Machado, S., Gourlie, J. A., Pritchett, L. C., Yan, G. P., and Jacobsen, E. E. 2013. Effects of crop rotation and tillage on Pratylenchus spp. in the semi-arid Pacific Northwest United States. Plant Dis. 97:537546.

25. Smiley, R. W., Merrifield, K., Patterson, L.-M., Whittaker, R. G., Gourlie, J. A., and Easley, S. A. 2004. Nematodes in dryland field crops in the semiarid Pacific Northwest USA. J. Nematol. 36:54-68.

26. Smiley, R. W., and Nicol, J. M. 2009. Nematodes which challenge global wheat production. Pages 171-187 in: Wheat Science and Trade. B. F. Carver, ed. Wiley-Blackwell, Ames, IA.

27. Smiley, R. W., Whittaker, R. G., Gourlie, J. A., and Easley, S. A. 2005a. Pratylenchus thornei associated with reduced wheat yield in Oregon. J. Nematol. 37:45-54

28. Smiley, R. W., Whittaker, R. G., Gourlie, J. A., and Easley, S. A. 2005b. Suppression of wheat growth and yield by Pratylenchus neglectus in the $\mathrm{Pa}$ cific Northwest. Plant Dis. 89:958-968.

29. Smiley, R. W., Whittaker, R. G., Gourlie, J. A., and Easley, S. A. 2006 Geocenamus brevidens associated with reduced yield of no-till annual spring wheat in Oregon. Plant Dis. 90:885-890.

30. Strausbaugh, C. A., Bradley, C. A., Koehn, A. C., and Forster, R. L. 2004 Survey of root diseases of wheat and barley in southeastern Idaho. Can. J. Plant Pathol. 26:167-176.

31. Taylor, S. P., Vanstone, V. A., Ware, A. H., McKay, A. C. Szot, D., and Russ, M. H. 1999. Measuring yield loss in cereals caused by root lesion nematodes (Pratylenchus neglectus and P. thornei) with and without nematicides. Aust. J. Agric. Res. 50:617-622.

32. Thompson, A. L. 2013. Identifying root-lesion nematode (Pratylenchus spp.) resistance and functional mechanisms in wheat. Ph.D. dissertation, Department of Crop and Soil Sciences, Washington State University, Pullman. https://research.wsulibs.wsu.edu:8443/xmlui/handle/2376/4979

33. Thompson, A. L., Sheedy, J. G., Campbell, K. G., Okubara, P. A., and Smiley, R. W. 2008. Resistance of wheat to the root lesion nematode; Pratylenchus thornei. Plant Dis. Manage. Rep. 2:N039.

34. Thompson, J., Owen, K., Clewett, T., Sheedy, J., and Reen, R. 2009. Management of root-lesion nematodes in the northern grain region. Queensland Primary Industries and Fisheries, DEEDI, Brisbane. http://www.daff.qld. gov.au/_data/assets/pdf_file/0010/58870/Root-Lesion-Nematode-Bro chure.pdf

35. Thompson, J. P., Brennan, P. S., Clewett, T. G., Sheedy, J. G., and Seymour, N. P. 1999. Progress in breeding wheat for tolerance and resistance to rootlesion nematode (Pratylenchus thornei). Australas. Plant Pathol. 28:45-52.

36. Thompson, J. P., Mackenzie, J., and Amos, R. 1995. Root-lesion nematode (Pratylenchus thornei) limits response of wheat but not barley to stored soil moisture in the Hermitage long-term tillage experiment. Aust. J. Exp. Agric. 
35:1049-1055.

37. Thompson, J. P., Mackenzie, J., and Sheedy, G. H. 2012. Root-lesion nematode (Pratylenchus thornei) reduces nutrient response, biomass and yield of wheat in sorghum-fallow-wheat cropping systems in a subtropical environment. Field Crops Res. 137:126-140.

38. Thompson, J. P., O'Reilly, M. M., and Clewett, T. G. 2009. Resistance to the root-lesion nematode Pratylenchus thornei in wheat landraces and cultivars from the West Asia and North Africa (WANA) region. Crop Pasture Sci. 60:1209-1217.

39. Vanstone, V. A., Hollaway, G. J., and Stirling, G. R. 2008. Managing nematode pests in the southern and western regions of the Australian cereal industry: continuing progress in a challenging environment. Australas. Plant Pathol. 37:220-234.

40. Washington's Wheat Variety-2008 Crop. 2008. United States Department of Agriculture, National Agricultural Statistics Service. Washington, DC. http://www.nass.usda.gov/Statistics_by_State/Washington/Publications/Sma 11_Grains/whtvar08.pdf
41. Washington's Wheat Variety-2011 Crop. 2011. United States Department of Agriculture, National Agricultural Statistics Service, Washington, DC. http://www.nass.usda.gov/Statistics_by_State/Washington/Publications/Sma 11_Grains/whtvar11.pdf

42. Web Soil Survey. 2013. United States Department of Agriculture, Natural Resources Conservation Service, Washington, DC. http://websoilsurvey. nrcs.usda.gov/app/WebSoilSurvey.aspx

43. Yan, G. P., Smiley, R. W., and Okubara, P. A. 2012. Detection and quantification of Pratylenchus thornei in DNA extracted from soil using real-time PCR. Phytopathology 102:14-22.

44. Yan, G. P., Smiley, R. W., Okubara, P. A., Skantar, A., Easley, S. A., Sheedy, J. G., and Thompson, A. L. 2008. Detection and discrimination of Pratylenchus neglectus and $P$. thornei in DNA extracts from soil. Plant Dis. 92:1480-1487.

45. Yan, G. P., Smiley, R. W., Okubara, P. A., Skantar, A., and Reardon, K. L. 2013. Developing a real-time PCR assay for detection and quantification of Pratylenchus neglectus in soil. Plant Dis. 97:757-764. 